\title{
Thermal imaging of the effects of beta-irradiation on human body surface
}

\author{
by I. Benkō ${ }^{1}$, G.J. Köteles ${ }^{2}$ and G. Németh ${ }^{3}$
}

\begin{abstract}
"Technical University of Budapest, Department of Energy, H-1521 Budapest; ${ }^{2}$ "Frédéric Joliot-Curie" National Research institute for Radiobiology and Radiohygiene, H-1775 Budapest, POB. 101.; ${ }^{3}$ Haynal Imre" University of Health Sciences, Dept. of Radiotherapy, H-1389, POB.112., Budapest, Hungary
\end{abstract}

\begin{abstract}
It is an experience that ionising radiations produce thermal effects in human organisms. Nevertheless, very few data are available on the quantitative relationship of the dose of ionising radiation and the changes of temperature. The studies were planned, therefore, to reveal the thermal detectability of tissue reactions following radiotherapy treatments. By this way during the radiation treatments the thermal measurements made possible to detect the sequential alterations in the thermal map of the involved body surfaces. The thermal studies were performed in collaboration with the National Institute for Oncology by measurements of patients irradiated with beta rays. In the paper the results of infrared thermogrammetry investigations are given by histographic method.
\end{abstract}

\section{Introduction}

In the second half of the 20th century, the progress in thermographic (TG) and later in thermogrammetric (TGM) sciences considerably influenced not only the industry and engineering, but many branches of the biomedical sciences. In this regard, the field of radiological sciences is no exception $[1,2]$. However, the thermal effects caused by ionising radiation in the human body have not been investigated widely especially for local detection of pathological processes. Therefore, continuing our earlier investigations on the detection of radiation injuries [3-5,7-11] we have studied the temperature alterations of beta-irradiated body surfaces of radiotherapy patients $[6,12]$.

\section{Biological indicators of the radiation effect}

In case of an injury or a radiation treatment the amount of blood circulating through the region during irradiation is too small to contain enough lymphocytes to use them as carriers of chromosome aberrations. At the same time the local tissue reactions might be used to measure the effects of irradiation. Out of the cells of irradiated skin and subdermal tissues the endothelial cells covering the inner surfaces of vessels and representing the walls of capillaries are the most radiosensitive ones. The radiation causes first the dilatation of vessels, then due to the damage of capillaries and vessels the atrophy and necrosis of the tissues [Figure 6,7 and 8.]. The conditions of the vessels and the consequent tissue alterations can be followed by radioisotopic scintigraphy or through image formation by thermogrammetry $[4,5,8]$.

\section{Methods of examination}

The investigations on the beta-irradiated chest was performed by AGA THV 780 type infrared imaging equipment. The results of measurements were stored from the different investigations, during three weeks (see Figure 2 by an infrared video recording which was evaluated by computerised technique [Figure 3 and $A$ - colour plate].

The method of data analysis was developed and applied for the investigation of six patients. The irradiated areas as shown on Figure 1. have absorbed $2.5 \mathrm{~Gy}$ at each session but from various energies. The radiation treatment was performed through consecutive weeks, 5 irradiation sessions per week applied daily (see Figure 2), the beta-dose was 12 times $2.5 \mathrm{~Gy}$. The treatments on weekend days were omitted. 
The immediate effect could be seen already 20-30 minutes after irradiation (Figure 6,7 and 8.). These post-operative irradiations always complete the complex therapy of breast cancer patients.

\section{Analysis of temperature distribution by histographic processing}

Histographic analysis is the usual mode of processing experimentally and otherwise obtained sets of data, but it may be considered as an efficient way for describing temperature fields, too. Thereby there is still little experience available for such applications and for the proper evaluation of all histogram characteristics $[4,6,9]$.

In histograms which represent temperature fields of digital IR-images (Figure 3 and Figure A.), pixel numbers (in percentage) with the given temperature are plotted against temperatures occurring within the fields (e.g. Figure 4). Temperatures occurring in the selected area may be displayed both graphically (Figure 4 and 5) and digitally, and the obtained data lend themselves for further computations (Figure 6,7 and 8). In our practice satisfactory results were obtained when the temperature varied by tenths of degrees within the range.

Among essential values characteristic of the histograms, the following are pointed out: the highest (max), the lowest ( $\mathrm{min}$ ) and the average (avg) temperature in the defined area; mediane (med), standard deviation (Sdev) and skewness (Skew) (see Figure 3); number of pixels in the examined area ( $\mathrm{Ncal}$ ) and the maximum value on the ordinate of the histogram (Fmax) (e.g. Figure A.).

\section{Results and conclusion}

The details of observed results are indicated in the legends of the figures. Diagrams are given describing the temperature variation effects resulting from the beta-irradiation in function of the time of treatment, as well as versus cumulative absorbed beta-dose.

The results presented give evidence for the efficient use of infrared technique in diagnosis and follow-up of local beta-irradiation. Upon the former and present experience we suggest that infrared thermogrammetry can be used in detection of the extent of beta-irradiation even at doses which do not cause clinically significant signs and symptoms.

\section{Acknowledgement}

The authors highly acknowledge the contribution of Dr. med. Julia Petrányi (National Institute for Oncology, Budapest.).

\section{REFERENCES}

[1] KÖTELES (G.J.) and BIANCO (A.). - The need for and importance of biological indicators of radiation effects with special reference to injuries in radiation accidents. International Atomic Energy Agency, TECDOC-273, Vienna, p.7-22. 1982.

[2] KÖTELES (G.J.), BENKOீ (I.) and SZTANYIK (L.B.).- Thermography in diagnosis of local radiation injury, in "Trends in Biological Dosimetry", Proceedings of Intemational Symposium, Lerici, Italy, Wiley-Liss Publ., New York, 1991.

[3] KÖTELES (G.J.), BENKŐ (I.) - New data on application of thermogrammetry in diagnosis of local radiation injury. Mérés és Automatika (Measurement and Automation), 39, p.88-93, 1991.

[4] BENKÖ (1.) - Quantitative analysis of medical infrared pictures. Österreich Thermologie, 2 Sonderheft, p. 17, August, 1992.

[5] KÖTELES (G.J.), BENKŐ (l). - Infrared themogrammetry as a tool in radiation pathology. Osterreich Thermologie, 2, Sonderheft, p. 34, August 1992. 
[6] BENKÕ (1). - Histographical analysis of infrared images for medical diagnosis. 8th Int. Conf. on Thermal Engineering and Thermogrammetry, Budapest, Hungary, p. 307-308, 1993.

[7] KÖTELES (G.J.), BENKÕ (I.). - Infrared thermogrammetry as a tool in the diagnosis of ionising radiation caused local injuries. 8th Int. Conf. on Thermal Engineering and Thermogrammetry, Budapest, Hungary, p. 319-320, 1993.

[8] BENKÕ (l.), KÖTELES (G.J.). - Thermotechnical approaches to the investigation of local injuries caused by ionising radiation. Periodica Polytechnica, Ser. Mech. Eng. Vol. $37 . N^{\circ} 3$. Budapest, p.197-213., 1993.

[9] BENKŌ (I.). - Possibilities of infrared imagery in the field of biology of ionising radiation. Proceedings of the Workshop on Advanced Infrared Technology and Applications. Casa Malaparte - Capri (Italy), September 20-21, 1993. Fondazione "Giorgio Ronchi", Firenze, p. 255-270, 1994.

[10] BENKŌ (I.), KÖTELES (G.J.). - Recent data concerming human reactions against ionizing radiation. Proceedings of the "Recent Advances in Medical Thermology". 13-15 October, 1994. Bath, U.K. Thermologie Österreich, Vol. 4. No.4 p. 181-182., 1994.

[11] KÖTELES (G.J.), BENKÓ (I.). - Infrared thermogrammetry in the practice of radiobiology. Abstracts of 9th Int.Conf. on Thermal Engineering and Thermogrammetry (THERMO). Budapest, 14-16 June, 1995. p.136-137.

[12] KÖTELES (G.J.), BENKŌ (I.), NÉMETH (Gy), PETRÁNYI (J). - Thermal approach to the investigation of the effects of beta-irradiation. Abstracts of 9th int.Conf. on Thermal Engineering and Thermogrammetry (THERMO). Budapest, 14-16 June, 1995. p.138-139. 


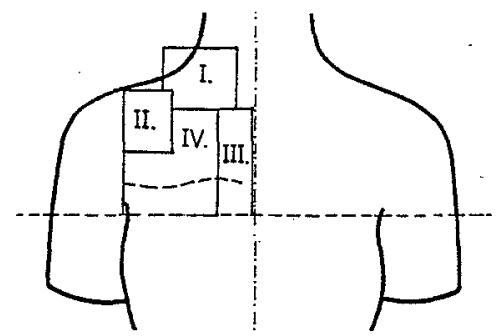

Fig.1. Various beta-irradiated areas on the chest of patient after operation of breast cancer (broken line indicates the scar of operation)

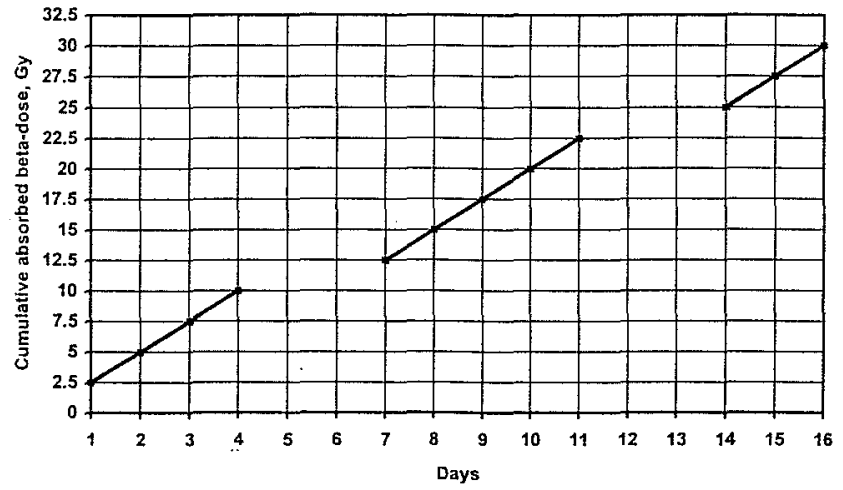

Fig.2. Cumulative absorbed beta-dose values during the treatment

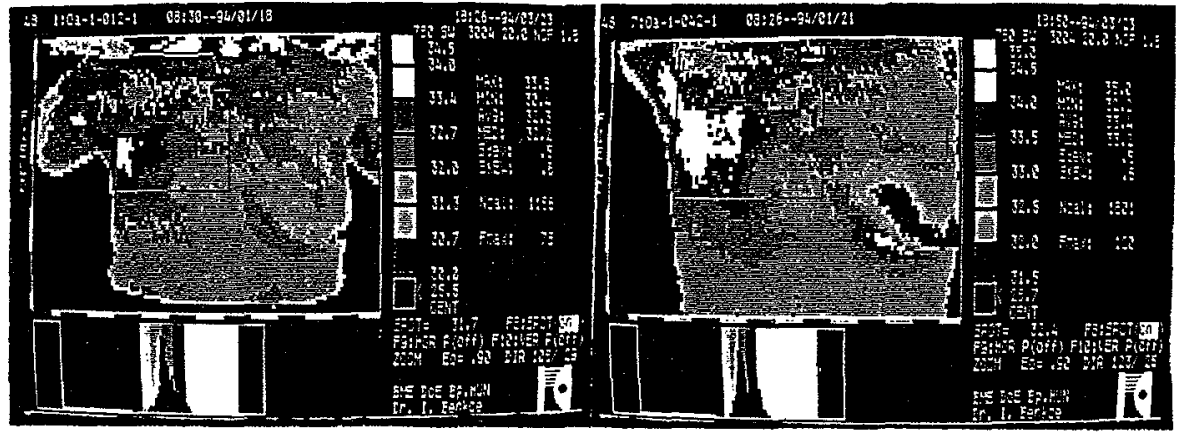

Fig. 3. Infra-red thermograms of female chest before (left figure) and on the 4th day during radiation treatment (right figure), evaluated by computerized histographic method 


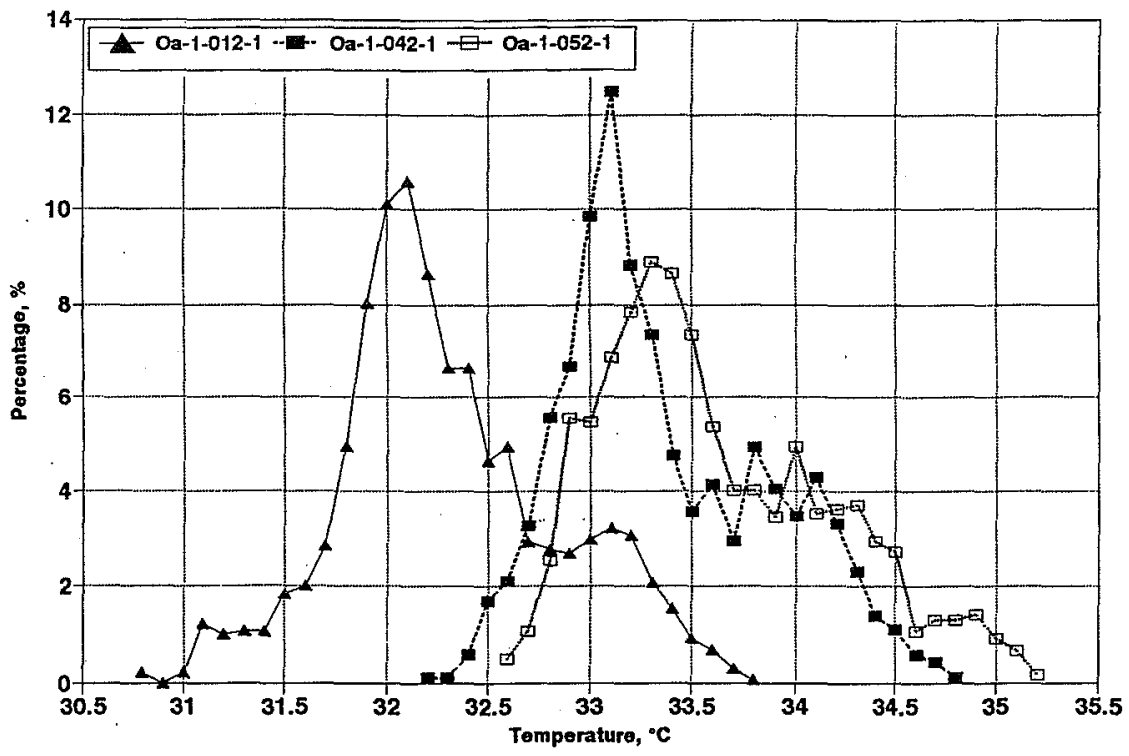

Fig. 4. Series of histograms of the temperature values on the beta-irradiated areas at the 1st (No. 012), 4th (No. 042) and 7th (No. 052) day during radiation treatment

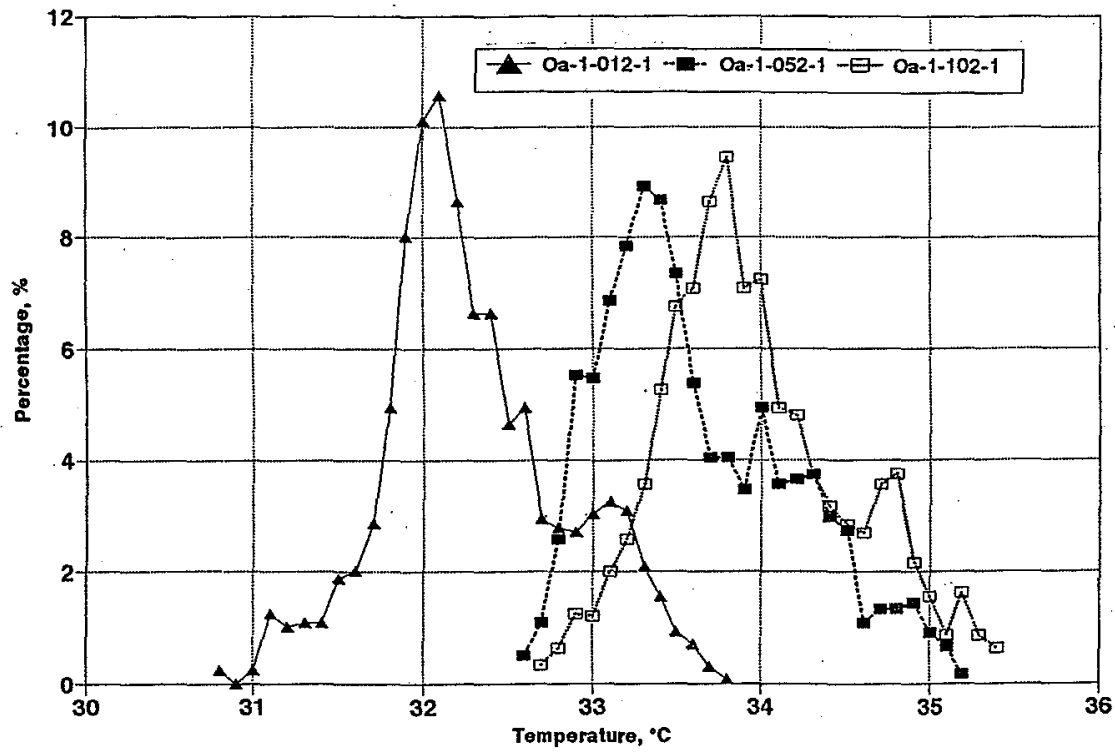

Fig. 5. Series of histograms of the temperature values on the beta-irradiated areas at the first day (No. 012), then at the end of first week (after 4 sessions, No. 052) and the second week (after 9 sessions, No. 102) 


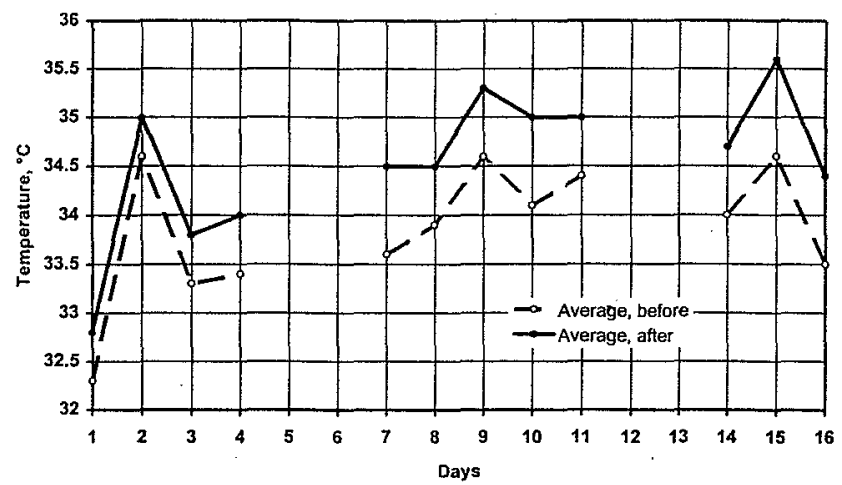

Fig. 6. Immediate changes of the average temperatures on the irradiated surfaces before and after each radiotherapy sessions

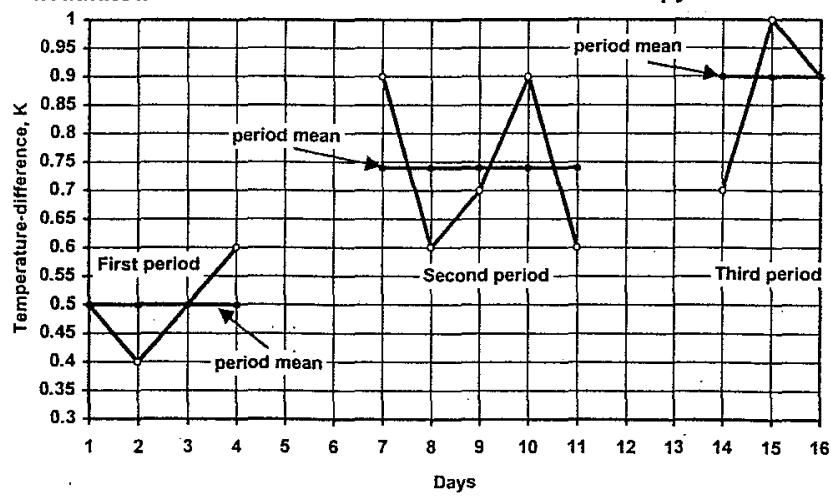

Fig. 7. Changes of average temperature differences as measured before and after radiotherapy sessions during the treatment (based on Fig. 6.)

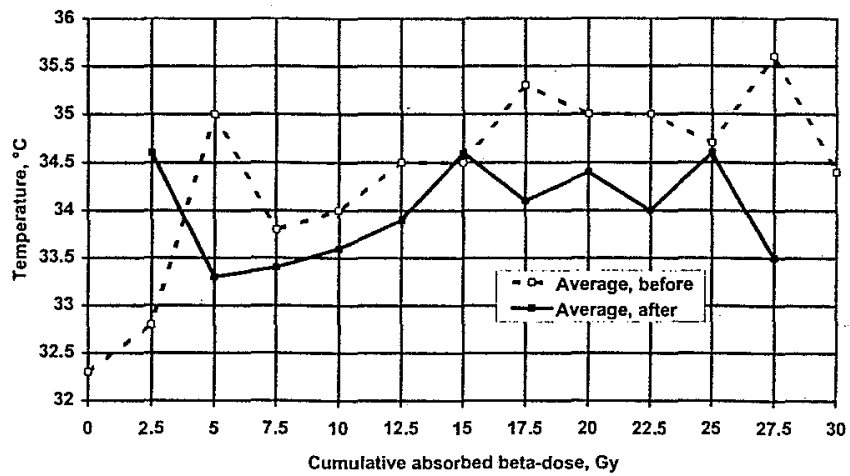

Fig. 8. Changes of average temperature values of irradiated area before and 24 hours after each irradiation in function of the cumulative absorbed beta-dose 